\title{
Prevalence and genotype of Chlamydia psittaci in faecal samples of birds from zoos and pet markets in Kunming, Yunnan, China
}

\author{
Yue FENG ${ }^{\S 1}$, Yue-mei FENG ${ }^{\S 2}$, Zhong-hua ZHANG ${ }^{1}$, Shao-xiong $\mathrm{WU}^{2}$, Du-bo ZHONG ${ }^{3}$, Chen-jian LIU $^{\dagger 11}$ \\ ( ${ }^{1}$ Faculty of Life Science and Technology, Kunming University of Science and Technology, Kunming 650500, China) \\ ( ${ }^{2}$ Academy of Public Health, Kunming Medical University, Kunming 650500, China) \\ ( ${ }^{3}$ Yunnan Yunce Quality Testing Co., Ltd., Kunming 650500, China) \\ †E-mail: newstaar8@hotmail.com \\ Received Apr. 16, 2015; Revision accepted Nov. 7, 2015; Crosschecked Mar. 15, 2016
}

\begin{abstract}
Chlamydia psittaci is an important zoonotic pathogen in birds and may be transmitted to humans and result in severe respiratory disease. To assess the prevalence and genotype of $C$. psittaci in birds in Kunming, Yunnan, China, a total of 136 specimens of psittacine birds involving 8 species were collected from the city's zoos $(n=60)$ and pet markets $(n=76)$. The frequency of $C$. psittaci infection was $19.9 \%(27 / 136)$ in the psittacine birds. The prevalence of C. psittaci was higher in pet birds $(26.3 \% ; 20 / 76)$ than in zoo birds $(11.7 \% ; 7 / 60)(P=0.034)$. In particular, among Agapornis fischeri, the C. psittaci infection $(50 \% ; 10 / 20)$ was significantly more frequent in the pet markets than in the zoos $(P=0.006)$. In addition, the highest prevalence of $41.2 \%(7 / 17)$ was found in Ara ararauna. To determine the genotype of $C$. psittaci, 23 OmpA gene fragments (about $1.4 \mathrm{~kb}$ ) in 27 positive samples were successfully amplified and sequenced. Phylogenetic analysis showed that all the 23 strains belonged to genotype $A$. Our results demonstrate the high prevalence of $C$. psittaci genotype A infection in psittacine birds in Yunnan Province, suggesting a potential threat to human health in this area. Therefore, it is necessary to take effective measures to prevent the spread of $C$. psittaci among psittacine birds, as well as among employees and customers.
\end{abstract}

Key words: Chlamydia psittaci, Genotype, OmpA, Prevalence, Yunnan http://dx.doi.org/10.1631/jzus.B1500091

CLC number: R374.2

\section{Introduction}

Chlamydia psittaci is a major causative agent of psittacosis. It most frequently infects Psittaciformes but can also infect many other avian species, as well as a wide range of mammalian hosts (Kaleta and Taday, 2003; Zhu et al., 2013). The highest infection rates are identified in psittacine birds and pigeons (Donham and Zejda, 1992; Pilny et al., 2012). It can infect humans by inhalation or close contact (Beeckman and Vanrompay, 2009). Human infection with $C$. psittaci can induce psittacosis, a disease that occasionally leads to severe pneumonia, headache,

\footnotetext{
Corresponding author

$\S$ The two authors contributed equally to this work

(1] ORCID: Yue FENG, http://orcid.org/0000-0002-2718-0836

(C) Zhejiang University and Springer-Verlag Berlin Heidelberg 2016
}

chills, malaise, and myalgia (Fraeyman et al., 2010; Osman et al., 2013). Human psittacosis is a notifiable disease in the USA, Australia, and most European countries (Harkinezhad et al., 2009a). There have been 6500 cases reported from 1996 to 2007 in these regions (Harkinezhad et al., 2009b). However, no vaccines or valid agents are available against $C$. psittaci.

Yunnan is the richest in bird species in China on account of its special geographical location and climate. It is reported that about 1288 species of birds inhabit China, most of which can be found in Yunnan (http://avibase.bsc-eoc.org). C. psittaci infection in birds is prevalent throughout the world (Geigenfeind et al., 2012). However, there is limited information on the prevalence and the genotypes of $C$. psittaci in China. The aim of this study was to assess the 
prevalence and the genotypes of $C$. psittaci in the faeces of birds from zoos and pet markets in Kunming City of Yunnan Province, China.

\section{Materials and methods}

\subsection{Ethics statement}

Before specimen collection, we contacted the administrators of the zoos and pet markets and obtained their permission to investigate their animals. All animal work followed guidelines in accordance with the Regulations for the Administration of Affairs Concerning Experimental Animals, and was approved by the Animal Ethical Committee of Kunming University of Science and Technology, China.

\subsection{Sample collection and DNA extraction}

A total of 136 fresh fecal samples from psittacine birds were collected from two zoos $(n=60)$ and five different pet markets $(n=76)$ in Kunming, Yunnan, China. Potassium dichromate was washed off fecal specimens with distilled water by centrifugation at $1500 \mathrm{~g}$ for $10 \mathrm{~min} 4$ times at room temperature. DNA was extracted from $200 \mathrm{mg}$ feces using QIAamp DNA Stool Mini kit (catalog No. 51304; Qiagen, Inc.) according to the manufacturer's instructions. The DNA was eluted into $200 \mu$ of Qiagen elution buffer and stored at $-70{ }^{\circ} \mathrm{C}$.

\subsection{Real-time PCR}

C. psittaci was detected by the TaqMan minor groove binder (MGB) fluorescent real-time quantitative polymerase chain reaction (qPCR) assay that targeted the $O m p A$ gene. The primers and probe were: forward, 5'-TGTGATTCACAAACCAAGAGGCTAT A-3'; reverse, 5'-CGAGGCCTACTTGCCATTCA-3'; probe, (FAM) 5'-TATGTTTAGGCATCTAAAAC-3' (MGB). In brief, the mixture for one reaction contained $12.5 \mu \mathrm{l}$ of $2 \times$ TaqMan universal PCR master mix, final concentrations of $900 \mathrm{nmol} / \mathrm{L}$ each of the forward and reverse primers, $250 \mathrm{nmol} / \mathrm{L}$ of MGB probe, and $1 \mathrm{pmol}$ of the template DNA, and nucleasefree water (catalog No. P1193; Promega) was added to give a final volume of $25 \mu \mathrm{l}$. Real-time PCR was performed with a Corbett Rotor-Gene 6000 (catalog No. $65 \mathrm{H} 0$; Corbett Life Sciences) under the following cycling conditions: 1 cycle at $50{ }^{\circ} \mathrm{C}$ for $2 \mathrm{~min}, 1$ cycle at
$95{ }^{\circ} \mathrm{C}$ for $10 \mathrm{~min}$, followed by 40 cycles at $95{ }^{\circ} \mathrm{C}$ for $15 \mathrm{~s}$ and $60^{\circ} \mathrm{C}$ for $1 \mathrm{~min}$.

\subsection{Amplification of $O m p A$ gene and sequencing}

All the $C$. psittaci-positive DNAs identified by TaqMan MGB real-time PCR were used to perform the amplification of major outer-membrane protein gene A $(O m p A)$ fragment as previously described (de Freitas Raso et al., 2006). The specific primers were as follows: 5GPF, 5'-ACGCATGCAAGACAC TCCAAAGCC-3' (forward primer); 3GPB, 5'-ACA AATTCCTAGGTTCTGATAGCGGGA-3' (reverse primer), generating a product of about $1460 \mathrm{bp}$. PCR reaction was carried out using the Premix Taq ${ }^{\mathrm{TM}}$ Hot Start version (TaKaRa, Dalian, China) under the following conditions: $95{ }^{\circ} \mathrm{C}$ for $5 \mathrm{~min}$, followed by 35 cycles at $95^{\circ} \mathrm{C}$ for $30 \mathrm{~s}, 56^{\circ} \mathrm{C}$ for $30 \mathrm{~s}$, and $72{ }^{\circ} \mathrm{C}$ for $2 \mathrm{~min}$, with a final extension $72{ }^{\circ} \mathrm{C}$ for $5 \mathrm{~min}$. Lastly, the obtained products were analyzed by agarose gel electrophoresis, the positive PCR products were purified using PCR Product Gel Extraction Kit (Tiangen, Beijing, China) and then were sequenced by Invitrogen Biotechnology Co. (Guangzhou, China).

\subsection{Phylogenetic analysis and genotyping}

To determine the genotype of C. psittaci, phylogenetic analysis was performed based on the 1460-bp OmpA gene fragments obtained. The representative sequences of $C$. psittaci involving genotypes $\mathrm{A}, \mathrm{B}, \mathrm{C}$, $\mathrm{D}, \mathrm{E}, \mathrm{E} / \mathrm{B}$, and $\mathrm{F}$ were downloaded from the GenBank database. Then, a dataset for the analysis of the $O m p A$ gene was composed of the reference sequences and the resulting sequences. The alignment and manual editing of multiple sequences generated were conducted using Clustal 1.8.3 and BioEdit 7.0, respectively. A phylogenetic tree was constructed using the neighbor-joining method based on the Kimura 2-parameter model with 1000 bootstrap replicates and a transition-transversion ratio of 2.0 applied in MEGA 6.02.

\subsection{Statistical analysis}

Differences in C. psittaci infection rates between zoos and pet markets were analyzed using the SPSS software (Release 18.0 standard version, SPSS Inc., Chicago, Illinois, USA). $P<0.05$ was considered statistically significant. 


\section{Results}

\subsection{Prevalence of $C$. psittaci}

A total of 136 specimens of psittacine birds were collected from zoos $(n=60)$ and pet markets $(n=76)$. The psittacine birds contained eight different subspecies, including Ara ararauna, Cacatua galerita, Agapornis fischeri, Psittacula eupatria, P. derbiana, Moustached parakeet, Melopsittacus undulatus, and $P$. cyanocephala. The infection rates of $C$. psittaci are given in Table 1 . The frequency of $C$. psittaci infection was $19.9 \%(27 / 136 ; 13.2 \%-26.6 \%)$ in the psittacine birds. From the subspecies of psittacine birds, Ara ararauna had the highest prevalence rate of 41.2\% (7/17; 17.8\%-64.6\%), followed by Agapornis fischeri 33.3\% (10/30; 16.5\%-50.2\%), Melopsittacus undulatus 20\% (4/20;2.5\%-37.5\%), P. eupatria $18.2 \%(2 / 11 ; 4.6 \%-40.9 \%)$ and Cacatua galerita $17.4 \%(4 / 23 ; 1.9 \%-32.9 \%)$. C. psittaci was detected in $26.3 \%(20 / 76 ; 16.4 \%-36.2 \%)$ and $11.7 \%(7 / 60$; $3.5 \%-19.8 \%$ ) of the samples from pet birds and zoo birds, respectively. The infection rate of $C$. psittaci in pet birds was significantly higher than that in zoo birds $(P=0.034)$. In particular, in Agapornis fischeri, C. psittaci infection $(10 / 20 ; 50 \%)$ was significantly higher in pet market birds than in zoo birds $(P=0.006)$. No other statistically significant difference was found between pet and zoo birds.

\subsection{Genotype analysis}

Among the positive samples of $C$. psittaci detected using real-time PCR, $23 \mathrm{OmpA}$ gene fragments (1.4 kb) were successfully amplified and sequenced, with a success rate of $85.2 \%(23 / 27)$. The sequences obtained shared $99.6 \%-100.0 \%$ nucleotide identity with each other, and had the highest similarities (99.5\%-99.9\%) with the MN Zhang strain derived from human $C$. psittaci infection. Phylogenetic analysis showed that all the 23 strains belonged to genotype A (Fig. 1).

\section{Discussion}

C. psittaci is an avian pathogen and is generally prevalent in wild birds, pet birds, and poultry. However, it can cause zoonotic disease in humans. Humans have been reported to face a particular risk for the transmission of $C$. psittaci from birds, especially Psittaciformes. The purpose of this investigation was to survey and collect baseline data in China on the prevalence of $C$. psittaci in psittacine birds. To our knowledge, the current study is the first report concerning the molecular epidemiology of $C$. psittaci in psittacine birds in Kunming, Yunnan, China.

In this study, $C$. psittaci was detected in 27 out of 136 fresh fecal samples (19.9\%) in psittacine birds using TaqMan MGB real-time PCR, which is a highly sensitive and specific technique for detecting chlamydial DNA. Previous studies have reported the prevalence of $C$. psittaci in pet birds, in market-sold adult chickens, ducks, and pigeons, and in the domestic goose, Anser domestica. Cong et al. (2013) investigated the frequency of $C$. psittaci infection among birds from markets in adult chickens (13.32\%), ducks $(38.92 \%)$, and pigeons $(31.09 \%)$. Later, the same group reported a $10.8 \%$ infection rate of $C$. psittaci in pet birds by the indirect haemagglutination assay (IHA) in Gansu Province (Cong et al., 2014). A recent study of $C$. psittaci infection among pet parrots

Table 1 Differences of Chlamydia psittaci infection between zoo birds and pet birds

\begin{tabular}{|c|c|c|c|c|c|}
\hline \multirow{2}{*}{ Psittacine species } & \multirow{2}{*}{$\begin{array}{c}\text { Total } \\
(\text { infection rate }(\%))^{*}\end{array}$} & \multicolumn{2}{|c|}{ Positive number/negative number } & \multirow{2}{*}{$\chi^{2}$} & \multirow{2}{*}{$P$-value } \\
\hline & & Zoo & Pet market & & \\
\hline Ara ararauna & $17(41.2)$ & $7 / 10$ & $0 / 0$ & & \\
\hline Cacatua galerita & $23(17.4)$ & $0 / 8$ & $4 / 11$ & 2.58 & 0.108 \\
\hline Agapornis fischeri & $30(33.3)$ & $0 / 10$ & $10 / 10$ & 7.50 & 0.006 \\
\hline Psittacula eupatria & $11(18.2)$ & $0 / 6$ & $2 / 3$ & 2.93 & 0.087 \\
\hline Psittacula derbiana & $9(0)$ & $0 / 4$ & $0 / 5$ & & \\
\hline Moustached parakeet & $9(0)$ & $0 / 5$ & $0 / 4$ & & \\
\hline Melopsittacus undulatus & $20(20.0)$ & $0 / 4$ & $4 / 12$ & 1.25 & 0.264 \\
\hline Psittacula cyanocephala & $17(0)$ & $0 / 6$ & $0 / 11$ & & \\
\hline Total & $136(19.9)$ & $7 / 53$ & $20 / 56$ & 4.52 & 0.034 \\
\hline
\end{tabular}

\footnotetext{
* The percentage is the infection rate of $C$. psittaci in the respective species. ${ }^{*}$ Statistical significance was determined by Fisher's exact test
} 


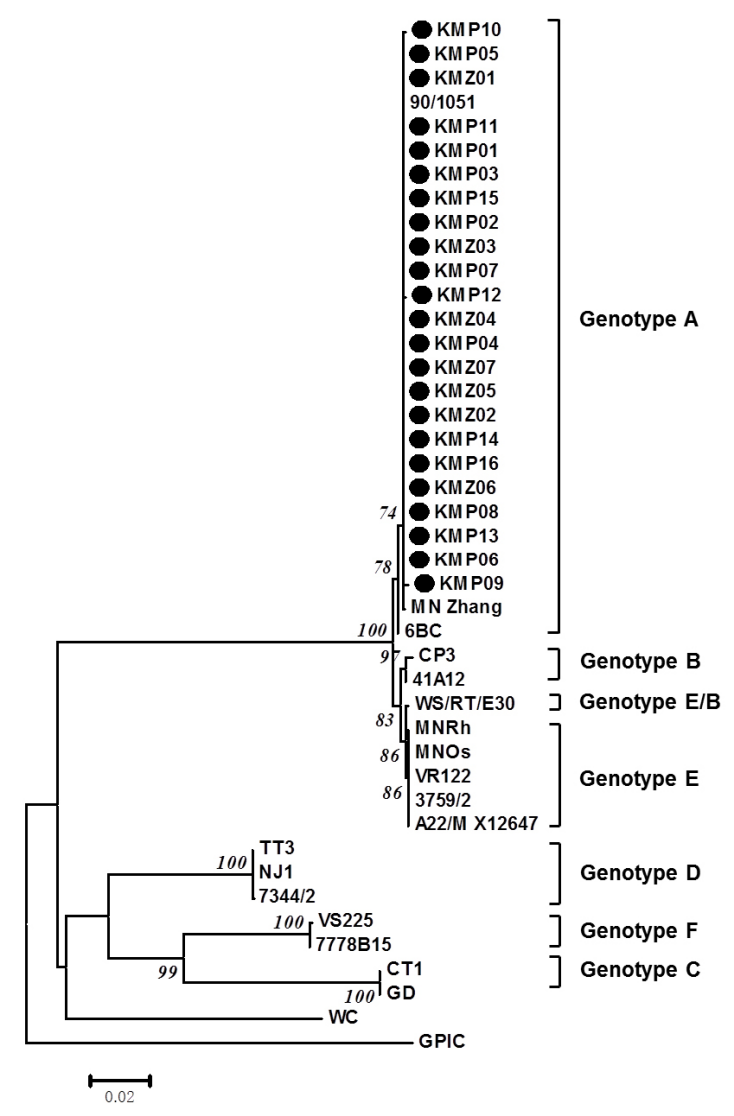

Fig. 1 Phylogenetic tree constructed by the neighbourjoining method based on partial nucleotide sequences of OmpA of C. psittaci (1054 bp)

The C. psittaci groups were indicated by alphabets A-F. Bootstrap value was shown if the reliability was greater than $70 \%$. The OmpA gene sequences obtained were submitted to GenBank and assigned accession numbers HM450387HM450409, respectively. The black circles showed the strains measured in this study

in the cities of Beijing and Weifang reported a prevalence of $35.37 \%$ (110/311) (Zhang et al., 2015). In addition, compared with the data of $C$. psittaci infection in other countries, the infection rate of $19.9 \%$ observed in psittacine birds in our study was higher than that in the Netherlands $(7.9 \%)$, but lower than that of $22.9 \%$ in Japan (Tanaka et al., 2005; Heddema et al., 2006). Taken together, it is difficult to compare different studies; the reasons may be due to differences in environment, diagnostic methods, feeding conditions, as well as animal husbandry practices and animal welfare.

In comparison, the overall prevalence of $C$. psittaci infection in psittacine birds in Yunnan Province was relatively higher than that in other Chinese provinces. Yunnan has a climate and geographical environment in which factors such as temperature, moisture, wetness, and landscape may make it easy for C. psittaci to establish infection and spread among birds.

Another important finding of this study is that the pet market specimens had a higher positive rate $(26.3 \%)$ of $C$. psittaci than the zoo samples $(11.7 \%)$ in psittacine birds $(P=0.034)$. This high frequency of $C$. psittaci infection in pet birds may be attributed to group feeding, mixed feeding, stacked cages, and lack of ventilation systems in the pet markets. Furthermore, pet-shop owners or caretakers may not clean up fecal debris or spilled food in a timely manner. The pet birds could be regarded as the potential reservoirs of zoonotic psittacosis and they may increase the risk of human infection in this region. Our results suggested that people who have contact with pets should be made aware of the possibility of contradicting psittacosis from their pets.

Our results indicated that the highest infection rate $(41.2 \%)$ was identified in Ara ararauna, suggesting that this is the most susceptible to $C$. psittaci among psittacine birds investigated. Of note, all the Ara ararauna with C. psittaci infection were from zoos. Regarding Ara ararauna and group feeding in zoos, the birds have limited space and remain as nestlings for longer. Therefore, once an outbreak of psittacosis is initiated, it easily spreads among Ara ararauna, in accordance with a previous report that the prevalence of $C$. psittaci is high among macaws (37.8\%) (de Freitas Raso et al., 2006). Furthermore, only the subspecies of Ara ararauna tested positively for C. psittaci DNA in psittacine birds from zoos, implying a single source of $C$. psittaci. Therefore, the relevant managerial staff should adopt effective measures to control the spread of the agent from Ara ararauna at the earliest.

Our results reveal a high prevalence of genotype A of $C$. psittaci in the Kunming region, supporting the conclusion that the $C$. psittaci genotype A was the major genotype associated with parrots (Zhang et al., 2015). In particular, previous studies reported an outbreak of psittacosis due to the C. psittaci genotype $\mathrm{A}$ in humans and birds, indicating that $C$. psittaci genotype A may be a strain capable of bird-tohuman transmission (Andersen, 1991; Vanrompay et al., 1997; Heddema et al., 2006). Thus, the high 
prevalence of genotype A of $C$. psittaci in this study should raise significant concerns. Although no petbird owners or veterinarians have ever presented with symptoms of psittacosis, further studies are necessary to investigate the prevalence and genotype of $C$. psittaci in the human population.

Our study had several limitations. First, comparisons of results from this study with previous $C$. psittaci infection epidemiological observations are difficult because of different test methods. Although the sensitivity of serological methods is low, the IHA was the most common method of determining $C$. psittaci infection in some previous investigations. However, we used a highly sensitive and specific technique of TaqMan MGB real-time PCR method. Second, our study used a small sample size and a single fecal specimen, and lacked some demographic information involving age, gender, and source.

\section{Conclusions}

The results of the present study revealed a high $C$. psittaci infection in psittacine birds in Yunnan, China, which poses a potential threat to human health in this area. Therefore, it is necessary to take effective measures to prevent the spread of $C$. psittaci among psittacine birds, as well as among employees and customers.

\section{Compliance with ethics guidelines}

Yue FENG, Yue-mei FENG, Zhong-hua ZHANG, Shaoxiong WU, Du-bo ZHONG, and Chen-jian LIU declare that they have no conflict of interest.

All institutional and national guidelines for the care and use of laboratory animals were followed.

\section{References}

Andersen, A.A., 1991. Serotyping of Chlamydia psittaci isolates using serovar-specific monoclonal antibodies with the microimmunofluorescence test. J. Clin. Microbiol., 29(4):707-711.

Beeckman, D.S., Vanrompay, D.C., 2009. Zoonotic Chlamydophila psittaci infections from a clinical perspective. Clin. Microbiol. Infect., 15(1):11-17. http://dx.doi.org/10.1111/j.1469-0691.2008.02669.x

Cong, W., Huang, S.Y., Zhang, X.Y., et al., 2013. Seroprevalence of Chlamydia psittaci infection in market-sold adult chickens, ducks and pigeons in north-western China. $J$. Med. Microbiol., 62(8):1211-1214. http://dx.doi.org/10.1099/jmm.0.059287-0

Cong, W., Huang, S.Y., Zhang, X.X., et al., 2014. Chlamydia psittaci exposure in pet birds. J. Med. Microbiol., 63(4): 578-581.

http://dx.doi.org/10.1099/jmm.0.070003-0

de Freitas Raso, T., Seixas, G.H., Guedes, N.M., et al., 2006. Chlamydophila psittaci in free-living Blue-fronted Amazon parrots (Amazona aestiva) and Hyacinth macaws (Anodorhynchus hyacinthinus) in the Pantanal of Mato Grosso do Sul, Brazil. Vet. Microbiol., 117(2-4):235-241. http://dx.doi.org/10.1016/j.vetmic.2006.06.025

Donham, K.J., Zejda, J.E., 1992. Lung dysfunction in animal confinement workers - chairman's report to the Scientific Committee of the Third International Symposium: issues in health, safety and agriculture, held in Saskatoon, Saskatchewan, Canada, May 10-15, 1992. Pol. J. Occup. Med. Environ. Health, 5(3):277-279.

Fraeyman, A., Boel, A., van Vaerenbergh, K., et al., 2010. Atypical pneumonia due to Chlamydophila psittaci: 3 case reports and review of literature. Acta Clin. Belg., 65(3):192-196. http://dx.doi.org/10.1179/acb.2010.040

Geigenfeind, I., Vanrompay, D., Haag-Wackernagel, D., 2012. Prevalence of Chlamydia psittaci in the feral pigeon population of Basel, Switzerland. J. Med. Microbiol., 61(2):261-265 http://dx.doi.org/10.1099/jmm.0.034025-0

Harkinezhad, T., Geens, T., Vanrompay, D., 2009a. Chlamydophila psittaci infections in birds: a review with emphasis on zoonotic consequences. Vet. Microbiol., 135(1-2):68-77. http://dx.doi.org/10.1016/j.vetmic.2008.09.046

Harkinezhad, T., Verminnen, K., de Buyzere, M., et al., 2009b. Prevalence of Chlamydophila psittaci infections in a human population in contact with domestic and companion birds. J. Med. Microbiol., 58(9):1207-1212. http://dx.doi.org/10.1099/jmm.0.011379-0

Heddema, E.R., ter Sluis, S., Buys, J.A., et al., 2006. Prevalence of Chlamydophila psittaci in fecal droppings from feral pigeons in Amsterdam, the Netherlands. Appl. Environ. Microbiol., 72(6):4423-4425. http://dx.doi.org/10.1128/AEM.02662-05

Kaleta, E.F., Taday, E.M., 2003. Avian host range of Chlamydophila spp. based on isolation, antigen detection and serology. Avian Pathol., 32(5):435-461. http://dx.doi.org/10.1080/03079450310001593613

Osman, K.M., Ali, H.A., ElJakee, J.A., et al., 2013. Prevalence of Chlamydophila psittaci infections in the eyes of cattle, buffaloes, sheep and goats in contact with a human population. Transbound. Emerg. Dis., 60(3):245-251. http://dx.doi.org/10.1111/j.1865-1682.2012.01337.x

Pilny, A.A., Quesenberry, K.E., Bartick-Sedrish, T.E., et al., 2012. Evaluation of Chlamydophila psittaci infection and other risk factors for atherosclerosis in pet psittacine birds. J. Am. Vet. Med. Assoc., 240(12):1474-1480. http://dx.doi.org/10.2460/javma.240.12.1474

Tanaka, C., Miyazawa, T., Watarai, M., et al., 2005. Bacteriological survey of feces from feral pigeons in Japan. $J$. Vet. Med. Sci., 67(9):951-953. http://dx.doi.org/10.1292/jvms.67.951 
Vanrompay, D., Butaye, P., Sayada, C., et al., 1997. Characterization of avian Chlamydia psittaci strains using omp 1 restriction mapping and serovar-specific monoclonal antibodies. Res. Microbiol., 148(4):327-333.

http://dx.doi.org/10.1016/S0923-2508(97)81588-4

Zhang, N.Z., Zhang, X.X., Zhou, D.H., et al., 2015. Seroprevalence and genotype of Chlamydia in pet parrots in China. Epidemiol. Infect., 143(1):55-61. http://dx.doi.org/10.1017/S0950268814000363

Zhu, D., Ikpatt, O.F., Dubovy, S.R., et al., 2013. Molecular and genomic aberrations in Chlamydophila psittaci negative ocular adnexal marginal zone lymphomas. Am. J. Hematol., 88(9):730-735.

http://dx.doi.org/10.1002/ajh.23490

\section{中文概要}

题 目: 云南省昆明市动物园和宠物市场中鸟类鹦陚热衣 原体的流行病学调查及其基因型分布研究

目 的: 调查云南省昆明市动物园和宠物市场的鹦形目鸟 类中鹦鹉热衣原体的流行情况。
创新点: 首次在云南地区开展鹦形目鸟类中鹦鹉热衣原体 的流行病学调查, 发现该地区鹦形目鸟类中具有 较高的鹦鹉热衣原体感染率。

方 法: 本研究共采集 8 种鹦形目鸟类的新鲜粪便样本 136 份, 其中动物园样本 60 份, 宠物市场样本 76 份。 首先, 利用高灵敏和高特异性的 TaqMan MGB 探 针荧光定量聚合酶链反应 (qPCR) 方法检测粪便 样品中鹦鹉热衣原体的感染率, 然后针对阳性样 品, 利用 PCR 技术进行鹦武热衣原体 $O m p A$ 基因 扩增、纯化、测序以及基因型分析。

结 论: 本实验结果显示: 鹦鹉热衣原体的感染率为 $19.9 \%$ （27/136），其中宠物市场鸟类中鹦鸫热衣原体 的感染率 $(26.3 \% ; 20 / 76)$ 明显高于动物园 $(11.7 \%$; $7 / 60 ） （ P=0.034 ）$; 金刚鹦武中感染率最高, 达 $41.2 \%$ （7/17）。同缘关系进化树分析表明, 这些 鹦鹉热衣原体都属于易于由鸟向人跨物种传播 的 A 型。综上所述, 昆明地区鹦形目鸟类中具有 较高的鹦鹉热衣原体流行, 给饲养人员和观鸟者 的健康带来了潜在的威胁。

关键词: 鹦鹉热衣原体; 基因型; $O m p A$ 基因; 流行病调 查; 云南 